Research Article

\title{
Functional abilities of cultivable plant growth promoting bacteria associated with wheat (Triticum aestivum L.) crops
}

Fernanda da S. Moreira ${ }^{1, \#}$, Pedro B. da Costa $^{1, \#}$, Rocheli de Souza ${ }^{1}$, Anelise Beneduzi ${ }^{2}$, Bruno B. Lisboa ${ }^{2}$, Luciano K. Vargas $^{2}$ and Luciane M. P. Passaglia ${ }^{1}$

${ }^{1}$ Departamento de Genética, Instituto de Biociências, Universidade Federal do Rio Grande do Sul, Porto Alegre, RS, Brazil.

${ }^{2}$ Fundação Estadual de Pesquisa Agropecuária, Porto Alegre, RS, Brazil.

\begin{abstract}
In the pursuit of sustainable agriculture, bioinoculants usage as providers of a crop's needs is a method to limit environmental damage. In this study, a collection of cultivable putative plant growth promoting (PGP) bacteria associated with wheat crops was obtained and this bacterial sample was characterized in relation to the functional diversity of certain PGP features. The isolates were obtained through classical cultivation methods, identified by partial $16 S$ rRNA gene sequencing and characterized for PGP traits of interest. Functional diversity characterization was performed using Categorical Principal Component Analysis (CatPCA) and Multiple Correspondence Analysis (MCA). The most abundant genera found among the 346 isolates were Pseudomonas, Burkholderia, and Enterobacter. Occurrence of PGP traits was affected by genus, niche, and sampling site. A large number of genera grouped together with the ability to produce indolic compounds; phosphate solubilization and siderophores production formed a second group related to fewer genera, in which the genus Burkholderia has a great importance. The results obtained may help future studies aiming prospection of putative plant growth promoting bacteria regarding the desired organism and PGP trait.
\end{abstract}

Keywords: plant growth promoting bacteria; Categorical Principal Component Analysis; functional analysis; Burkholderia genus.

Received: May 27, 2015; Accepted: August 24, 2015.

\section{Introduction}

Since the description of the association of non-symbiotic diazotrophic bacteria with non-legume plants (Baldani et al., 1983), free-living bacteria have demonstrated positive effects in promoting plant growth, proving their agronomic potential not only through biological nitrogen fixation (e.g., James et al., 2002; Ambrosini et al., 2012). These organisms present in the rhizosphere, root surfaces or inside plant tissues are able to directly or indirectly induce plant growth, as well as resistance to or protection against pathogens (Lugtenberg and Kamilova, 2009). The combination of nitrogen fixation with other features of plant growth promoting (PGP) has shown that all these benefic bacteria, collectively called plant growth promoting bacteria (PGPB), are an efficient and viable alternative to chemical fertilizers to achieve maximum production with environmental conservation (Kennedy et al., 2004).

Send correspondence to Luciane M. P. Passaglia, Departamento de Genética, Instituto de Biociências, UFRGS, Av. Bento Gonçalves, 9500, Caixa Postal 15.053, Prédio 43312, sala 207b, 91501970 Porto Alegre, RS, Brazil. E-mail: luciane.passaglia@ufrgs.br \# F. S. M and P. B. C. contributed equally to this work and should both be considered as first author.
Plant traits shape the conditions for microbial colonization mostly due to organic compounds released from the roots. A fine coordinated interaction between the variety of exudates excreted by the plant and individual characteristics of distinct microbial populations is a crucial aspect of driving selection (Dennis et al., 2010). However, from bacteria selected for rhizosphere colonization, only a small parcel can actually be commercially used. In addition, concerning biotechnological purposes, the selective effects on the rhizosphere microbiota is expected to be very complex. Only at the right set of conditions, a targeted effect on the behavior of a certain microbial subpopulation, e.g. an introduced inoculum, which is supposed to get established and interactive with the plant root, is possible (Hartmann et al., 2009).

While species diversity comprises richness and equitability (i.e., the total number of species and distribution among species, respectively), functional diversity is the value and range of the functional traits of the organisms in a given ecosystem (Tilman, 2001). Functional diversity affects ecosystem dynamics, stability, productivity and nutritional balance, among other aspects of a functioning ecosystem (Tilman, 2001). Joint investigation of cultivable 
(by traditional isolation) and non-cultivable diazotrophic and PGP bacteria can enable the description and analysis of almost the entire composition and structure of active plant growth promoting bacterial communities (Wartiainen et al. 2008). For biotechnological applications, the characterization of these organisms relies more often on culturedependent methods to search, characterize and better understand the diversity of functions involved in promoting plant growth. Numerous studies have demonstrated the heterogeneity in composition of bacterial community structure of bulk soil relative to the rhizospheric bacterial community, such as between root zones (Dennis et al., 2010). The objectives of this study were to isolate, identify and characterize a large number of putative diazotrophic and PGP bacteria associated with wheat crops. We were able to characterize this specific bacterial population concerning the functional diversity of its PGP features associated to the sampling sites and colonization niche (either roots or rhizospheric soil), identifying in which way the heterogeneity of PGP traits was presented. The associations here suggested may help in further studies on bioprospection that covers the interactions between genera, their roles (different characteristics of PGP), and niche occupancy.

\section{Materials and Methods}

\section{Sampling and location}

Wheat plants (Triticum aestivum L., cv. Guamirim, three plants from each sampling site) and their respective rhizospheric soils were collected from six wheat-producing regions in Rio Grande do Sul, Brazil: São Borja (SB; 2839'39''S, 56 00'14' 'W), Júlio de Castilhos (JC;

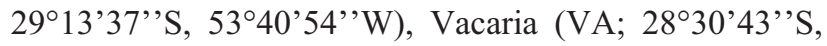
$50^{\circ} 56^{\prime} 02^{\prime \prime} \mathrm{W}$ ), Campina das Missões (CM; 27⒌'20''S, $\left.54^{\circ} 50^{\prime} 22^{\prime \prime} \mathrm{W}\right)$, Guarani das Missões (GM; 28 $08^{\prime} 27^{\prime \prime} \mathrm{S}$, $54^{\circ} 33^{\prime} 29^{\prime \prime} \mathrm{W}$ ), and Boa Vista do Cadeado (BV; $28^{\circ} 35^{\prime} 06^{\prime \prime}$ 'S, $\left.53^{\circ} 47^{\prime} 57^{\prime \prime} \mathrm{W}\right)$. Sampling of mature crops was performed in September: in 2010 for the SB, JC, and VA localities; and in 2011 for the CM, GM, and BV localities. All sites were maintained under standard fertilization condi- tions for wheat culture for over ten years. Three soil samples from each sampling site were also collected at $20 \mathrm{~cm}$ depth, bulked and analyzed for $\mathrm{pH}$, phosphorus, potassium, organic matter, and clay contents using standard methods (Table 1; Helmke and Sparks, 1996; Kuo, 1996; Mulvaney, 1996; Nelson and Sommers, 1996).

\section{Isolation of putative diazotrophic bacteria}

Putative diazotrophic bacteria were isolated from roots and rhizospheric soil of three sampled plants (that were pooled to compose one composite sample) from each sampling site. The roots were superficially disinfested by immersing in $70 \%$ ethanol for $1 \mathrm{~min}$ and $4 \%$ hypochlorite solution for $2 \mathrm{~min}$ followed by rinsing five times with sterile distilled water. After disinfestation, roots were sliced with a sterile scalpel. Ten grams of sliced roots and rhizospheric soil (manually detached from the roots) from each sampling site were separately placed into sterile 250-ml Erlenmeyer flasks containing $90 \mathrm{~mL}$ of sterile saline solution $(0.85 \% \mathrm{NaCl})$. Isolation of bacteria was performed according to Döbereiner (1988). Briefly, the samples were incubated at $4{ }^{\circ} \mathrm{C}$ with agitation $(125 \mathrm{rpm}$ ) for 4-6 h, subjected to serial dilutions in saline solution, inoculated and reinoculated for seven days into semi-solid, nitrogen-free media $\mathrm{NFb}$, LGI, and LGI-P to allow pellicles formation, and finally streaked onto agar plates supplemented with a nitrogen source (yeast extract). Bacterial isolates were randomly selected from the plates. Each isolate was inoculated into liquid LB medium (Sambrook and Russel, 2001) at $28^{\circ} \mathrm{C}$ under agitation (200 rpm) and bacterial cultures were stained using the Gram method to certify their purity; after that, the isolates were stored in $20 \%$ sterile glycerol at $-20^{\circ} \mathrm{C}$.

\section{Molecular identification}

Extractions of genomic DNA from bacterial cultures grown in LB medium, for $72 \mathrm{~h}$, at $28^{\circ} \mathrm{C}$ were performed using a phenol-chloroform and ethanol precipitation protocol as described by Sambrook and Russel (2001).

Table 1 - Soil abiotic characteristic at sampling sites.

\begin{tabular}{|c|c|c|c|c|c|}
\hline \multirow[b]{2}{*}{ Sampling site } & $\mathrm{P}^{\mathrm{a}}$ & $\mathrm{K}^{\mathrm{b}}$ & Clay & $\mathrm{OMC}^{\mathrm{c}}$ & \multirow{2}{*}{$\frac{\mathrm{pH}}{\mathrm{H}_{2} \mathrm{O}}$} \\
\hline & \multicolumn{2}{|c|}{$\mathrm{mg} \mathrm{kg}^{-1}$} & \multicolumn{2}{|c|}{$\%$} & \\
\hline Júlio de Castilhos & 24.3 & 166 & 38 & 3 & 5.1 \\
\hline São Borja & 13.5 & 158 & 26 & 4.8 & 5.3 \\
\hline Vacaria & 6.5 & 151.3 & 42.9 & 5.6 & 6.0 \\
\hline Campina das Missões & 18.9 & 167 & 36 & 2.3 & 5.4 \\
\hline Guarani das Missões & 27.2 & 148 & 37 & 3.7 & 5.8 \\
\hline Boa Vista do Cadeado & 9.6 & 86 & 61 & 2.8 & 5.5 \\
\hline
\end{tabular}

${ }^{\mathrm{a}} \mathrm{P}=$ extractable phosphorus;

${ }^{\mathrm{b}} \mathrm{K}=$ extractable potassium;

${ }^{\mathrm{c}} \mathrm{OMC}=$ organic matter content. 
The genomic DNA extracted from all isolates was submitted to partial 16S rRNA gene amplification $(\sim 450$ bp) using primers U968 (AACGCGAAGAA CCTTAC) and L1401 (CGGTGTGTACAAGACCC, Felske et al., 1997). Amplification reactions were performed using approximately $50 \mathrm{ng}$ of DNA template in $25 \mu \mathrm{L}$ reactions containing $20 \mu \mathrm{M}$ of each dNTP (Ludwig Laboratories), $0.05 \mu \mathrm{M}$ of each primer, $1 \mathrm{mM} \mathrm{MgCl} 2$ and 1 U Taq polymerase (Invitrogen ${ }^{\circledR}$ ) in 1 X Taq Buffer. Amplification of 16S rRNA gene portions was carried out under the following conditions: an initial denaturation step at 94 ${ }^{\circ} \mathrm{C}$ for $5 \mathrm{~min}, 30$ cycles at $94{ }^{\circ} \mathrm{C}$ for $45 \mathrm{~s}, 52^{\circ} \mathrm{C}$ for $45 \mathrm{~s}, 72$ ${ }^{\circ} \mathrm{C}$ for $45 \mathrm{~s}$, and a final elongation cycle at $72{ }^{\circ} \mathrm{C}$ for $10 \mathrm{~min}$. Sanger sequencing was performed on a $3500 x \mathrm{x}$ Genetic Analyzer (Applied Biosystems ${ }^{\circledR}$ ) using the DY EnamicTM ET Dye Terminator Cycle Sequencing Kit (GE HealthCare).

Sequences were trimmed to exclude low quality sequenced nucleotides. Data obtained from sequencing were compared to sequences available from the EzTaxon-e Server, which is an extension of the EzTaxon database. The nucleotide sequences of the partial 16S rRNA gene segments determined in this study have been deposited in the GenBank database (accession numbers KC254895 to KC255222).

\section{Evaluation of plant growth promotion characteristics}

All isolates were evaluated for their capacity to produce indolic compounds (ICs) and siderophores, as well as their ability to solubilize phosphate (as tricalcium phosphate) using three replicates and appropriate controls (i.e. non-inoculated media, inoculated media with known producers/solubilizers strains).

The production of ICs was evaluated according to Glickmann and Dessaux (1995) and Ambrosini et al. (2012). ICs production was ranked in levels as follows: bacterial isolates producing less than $17 \mu \mathrm{g}$ of ICs ml ${ }^{-1}$ were considered level 1 ICs producers (IC1); those that produced between $17 \mu \mathrm{g}$ and $80 \mu \mathrm{g}$ of ICs ml ${ }^{-1}$ were considered level 2 ICs producers (IC2); and those that produced more than $80 \mu \mathrm{g}$ of ICs $\mathrm{ml}^{-1}$ were considered level 3 ICs producers (IC3).

Siderophores production was evaluated according to Schwyn and Neilands (1987). After incubation for 48-72 h at $28{ }^{\circ} \mathrm{C}$, the formation of a yellow, orange or violet halo around the colonies denoted their ability to produce and release siderophore molecules. Likewise, a clear halo around a colony indicated that it was able to solubilize the phosphate source (provided as tricalcium phosphate) in glucose yeast (GY) medium as described by Ambrosini et al. (2012). Evaluation of these two abilities was conducted based on the size of the halo formed around bacterial colonies: isolates without a halo $($ halo $=0 \mathrm{~cm})$ were labeled either non-siderophore producers (level 1 - Sid1) or non-phosphate solubilizers (level 1 - Phos1); isolates with a halo wider than $0 \mathrm{~cm}$ up to $1 \mathrm{~cm}$ were considered either level 2 siderophore producers (Sid2) or level 2 phosphate solubilizers (Phos2), and isolates with a halo bigger than 1 $\mathrm{cm}$ were considered either level 3 siderophore producers (Sid3) or level 3 phosphate solubilizers (Phos3).

\section{Statistical analysis}

The composition of the bacterial sample communities, identified by the bacterial genera at each sampling site for both roots and rhizospheric soils (referred to here as niches) was used to determine the Shannon diversity index $\left(H^{\star}\right.$, Shannon and Weaver, 1949). The correlation between soil properties and microbial genetic diversity was determined via Principal Component Analysis (PCA) using a correlation matrix (with mean centering) to calculate eigenvalues and eigenvectors (Figure 1).

To better understand and facilitate the visualization of functional diversity, the categorical data (i.e., genera, ranked PGP traits, sampling sites, and niches) was analyzed by Categorical Principal Component Analysis (CatPCA) and Multiple Correspondence Analysis (MCA). MCA is similar to PCA for qualitative data accounting only for multiple nominal variables, without ordering them in a scale, such as in the case of genera and sampling sites. CatPCA, on the other hand, was used to account for the ordination of the different PGP levels, mixed with multiple nominal variables such as genera. Both methods provide easy representation and interpretation of categorical data by reducing a large number of variables into a two-dimensional map, con-

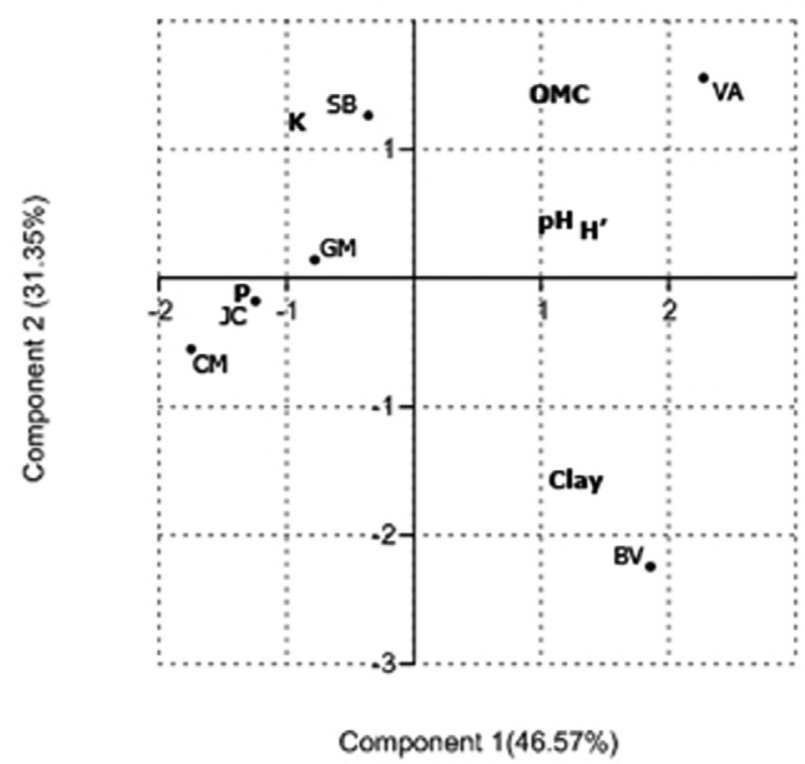

Figure 1 - Principal Component Analysis (PCA) of diversity indices in relation to soil abiotic properties [clay, organic matter content $(\mathrm{OMC}), \mathrm{pH}$, $\mathrm{P}, \mathrm{K}$,] determined from the six sampling sites (JC - Júlio de Castilhos, SB - São Borja, VA - Vacaria, CM - Campina das Missões, GM - Guarani das Missões, and BV - Boa Vista do Cadeado). Principal component 1 and component 2 accounted for $46.57 \%$ and for $31.35 \%$ of the total variation, respectively. 
sidering the frequency and homogeneity of the events to connect points (Hoffman, 1992). Thus, the generated hypothesis (null hypothesis of homogeneity) can be tested through a chi-square test via a contingency table and adjusted residual analysis, as in this study. The differences were considered significant for standardized adjusted residues $<1.96$. We used IBM SPSS Statistics to build the MCA and CatPCA analyses. On the input table for both figures, each line was representative of a single isolate. For MCA (Figure 2), both PGP traits and genera information are held in the columns (Table S1), while for CatPCA (Figure 3 ) the columns are for genera, niche and sampling site (Table S2). Each dot in the plot represents the average position for the different categories of every variable.

\section{Results}

\section{Isolation, identification and genera diversity of} putative diazotrophic bacteria

A total of 346 bacterial isolates were obtained from the six sampling sites. Among them, 328 were assigned to 36 distinct genera (according to the closest match in the
Ez-taxon database, considering a minimum of $97 \%$ of similarity, shown in Table 2), while 18 remained unidentified.

The most abundant and the only bacterial genus isolated in all the sampling sites and niches was Pseudomonas (46 isolates), representing $22 \%$ of all isolates, followed by strains belonging to the genera Burkholderia (17), Enterobacter (16), and Stenotrophomonas (12). These four genera were also the most ubiquitous, represented in at least five of the six sampling sites, comprising almost $60 \%$ of the bacteria isolated. The putative diazotrophic bacterial community analyzed was composed by 32 other genera, with the number of representative strains ranging from one to nine isolates, including various genera belonging to the Enterobacteriaceae family, such as Cedecea (8), Leclercia (8), and Klebsiella (4); and to the Xanthomonadaceae family, such as Xanthomonas (6) and Dyella (3). Gram positive bacteria were represented by four isolates belonging to the Microbacterium genus. Distribution of genera by sampling site and niche and their diversity indices are shown in Table 2 .

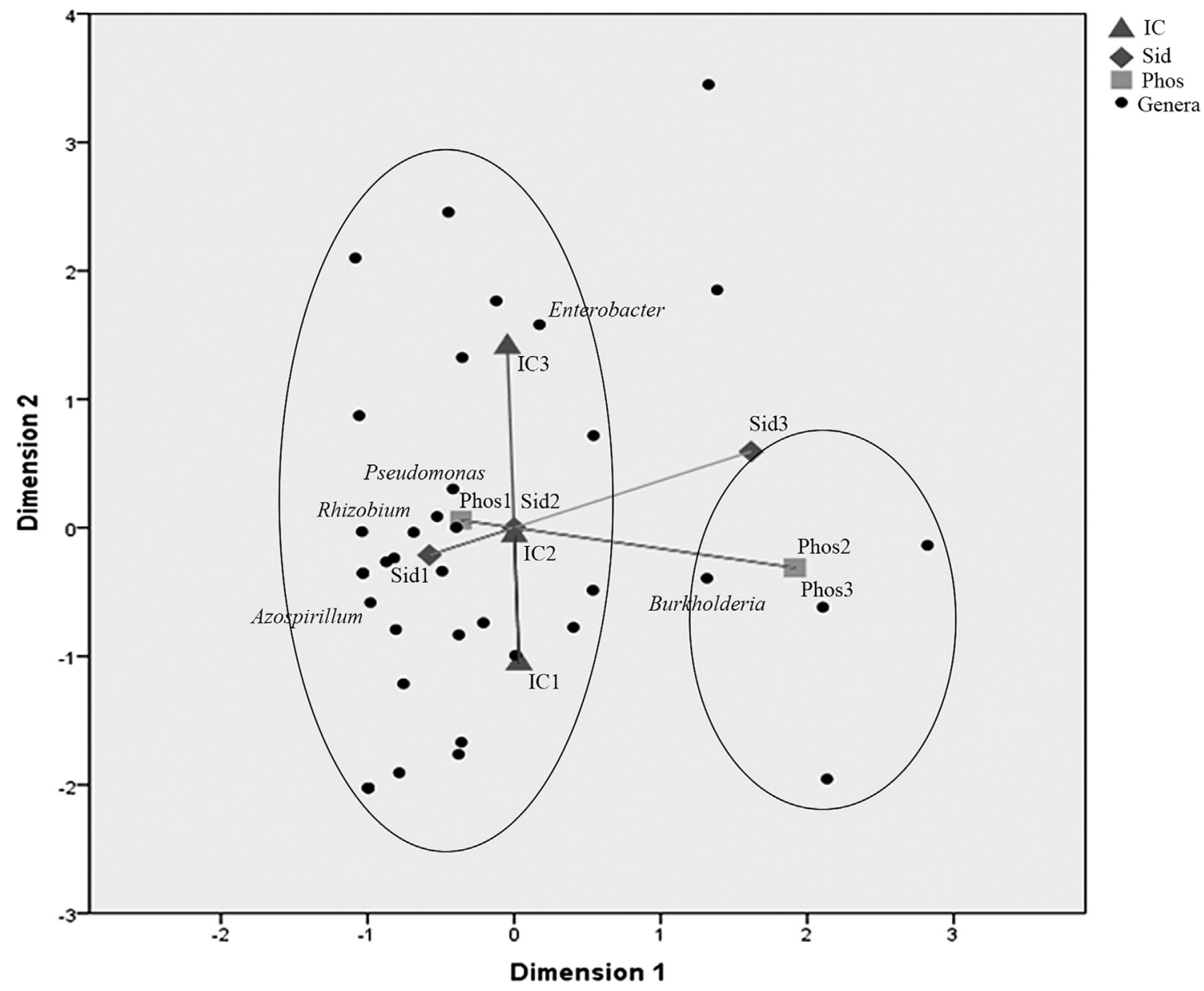

Figure 2 - Multiple Correspondence Analysis (MCA) of levels of PGP traits and genera. IC = indolic compounds production, Phos = phosphate solubilization, and $\mathrm{Sid}=$ siderophores production. Numbers following the abbreviation mean the level of the correspondent trait according with the score established. Dark spots represent all 36 genera identified; only the most abundant are identified in the plot. 


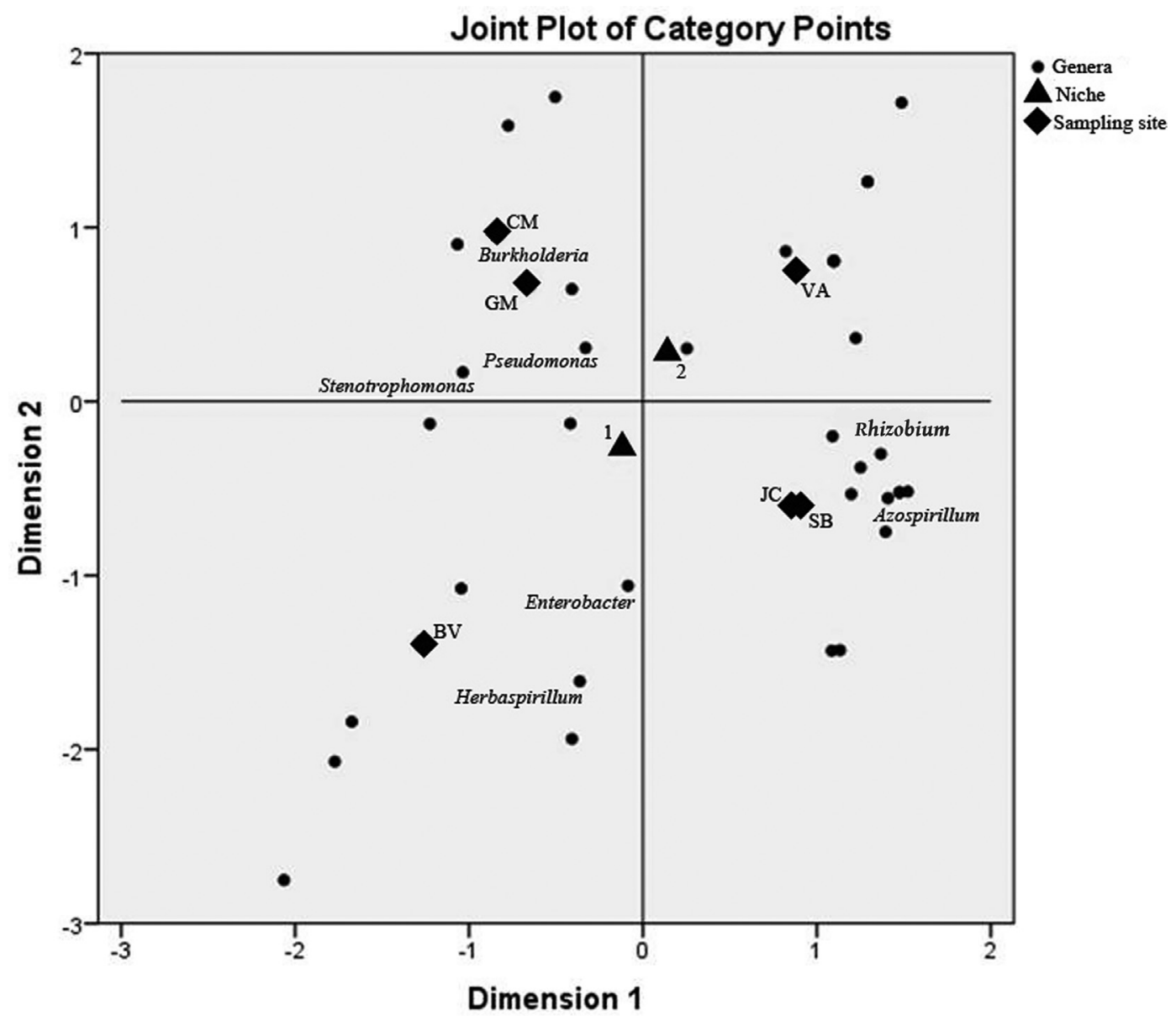

Figure 3 - Categorical Principal Component Analysis (CatPCA) of genera, niche $(1=$ roots, $2=$ rhizospheric soil), and sampling site $(\mathrm{JC}=\mathrm{Júlio}$ de Castilhos, $\mathrm{SB}=$ São Borja, VA = Vacaria, $\mathrm{CM}=$ Campina das Missões, $\mathrm{GM}=$ Guarani das Missões, and BV = Boa Vista do Cadeado). Dark spots represent all 36 genera isolated; only the most abundant are identified in the plot.

\section{Evaluation of plant growth promotion traits}

All isolates were evaluated for their ability to produce siderophores and indolic compounds and to solubilize phosphate under the given conditions. The results are listed in Table 3.

Phosphate solubilization was the rarest ability among the isolates, having occurred in 55 out of 346 isolates. Strains identified as phosphate solubilizers mainly belonged to the genus Burkholderia. The ability to produce siderophores was a common feature to several strains, especially of those belonging to the genera Pseudomonas and Burkholderia. Siderophores production was an ability also identified in several strains belonging to the Enterobacteriaceae family (Cedecea, Leclercia, Hafnia, Serratia, Klebsiella, Pantoea, and Shigella). While phosphate solubilization ability was more often found in isolates from rhizospheric soil, siderophore production was found in isolates more closely related to the roots. All isolates were able to produce indolic compounds, but with variable efficiency, ranging from $0.1 \mu \mathrm{g}$ to $640 \mu \mathrm{g}$ of ICs $\mathrm{ml}^{-1}$. The greatest IC producers belonged to the genera Enterobacter,
Pseudomonas, Azospirillum, Rhizobium, and Herbaspirillum. Those exhibiting all three abilities concurrently were mainly represented by strains belonging to the genus Burkholderia (17 isolates) and to members of the Enterobacteriaceae family (12 isolates).

\section{Soil characteristics and functional analysis of PGP traits}

Soil analysis (Table 1) showed that soil conditions at all sampling sites (namely, availability of nutrients and $\mathrm{pH}$ ) were in accordance with recommendations for wheat culture. Nevertheless, when Principal Component Analysis (PCA, Figure1) was used to visualize the relationships between abiotic soil parameters $(\mathrm{P}, \mathrm{K}$, clay, $\mathrm{pH}$, and $\mathrm{OM}$ contents) and bacterial diversity $\left(H^{6}\right)$, some differences could be observed. The first two dimensions of PCA explained $77.92 \%$ of the total variation, with principal component 1 (PC1) accounting for $46.57 \%$ and principal component 2 (PC2) for $31.35 \%$ of the variance. The major abiotic soil properties related to bacterial diversity $\left(H^{\star}\right)$ were $\mathrm{pH}$ and OM content (Figure 1). 
Table 2 - Heatmap associations of bacterial genera and occurrence of putative endophytic (Root) and rhizospheric (Soil) isolates. Different shades show whether a certain location had more or fewer bacteria, than expected, or whether there was no association. Black cells $=$ number of isolates lower than expected in that condition; dark shaded cells = number of isolates higher than expected in that condition; light shaded cells $=$ no significant differences between observed and expected values. "-" = association could not be calculated due to lack of cases (no comparable expected total marginal values), according to adjusted residual analysis $(p<0.05)$

\begin{tabular}{|c|c|c|c|c|c|c|c|c|c|c|c|c|}
\hline \multirow{2}{*}{$\begin{array}{l}\text { Sampling Site } \\
\text { Bacterial genera }\end{array}$} & \multicolumn{2}{|c|}{$\begin{array}{l}\text { Júlio de } \\
\text { Castilhos }\end{array}$} & \multicolumn{2}{|c|}{ São Borja } & \multicolumn{2}{|c|}{ Vacaria } & \multicolumn{2}{|c|}{$\begin{array}{l}\text { Campina das } \\
\text { Missões }\end{array}$} & \multicolumn{2}{|c|}{$\begin{array}{l}\text { Guarani das } \\
\text { Missões }\end{array}$} & \multicolumn{2}{|c|}{$\begin{array}{c}\text { Boa Vista do } \\
\text { Cadeado }\end{array}$} \\
\hline & Root & Soil $^{\mathrm{b}}$ & Root & Soil & Root & Soil & Root & Soil & Root & Soil & Root & Soil \\
\hline Achromobacter sp. & 1 & - & - & - & 1 & - & - & 1 & 1 & - & 1 & - \\
\hline Acinetobacter sp. & - & - & - & - & 1 & 1 & - & - & - & - & - & - \\
\hline Azorhizobium sp. & - & - & - & - & 2 & 2 & - & - & - & - & - & - \\
\hline Azospirillum sp. & 1 & 7 & 1 & 4 & 1 & - & - & - & - & - & - & - \\
\hline Burkholderia sp. & - & 2 & - & - & 1 & 4 & 9 & 17 & 7 & 5 & - & 8 \\
\hline Caulobacter sp. & - & - & - & 1 & - & - & - & - & - & - & - & - \\
\hline Cedecea sp. & 2 & 3 & - & 3 & - & - & - & - & - & - & - & - \\
\hline Chryseobacterium sp. & - & - & - & - & - & - & - & - & - & 1 & - & 1 \\
\hline Citrobacter sp. & - & - & - & - & - & - & - & - & - & 1 & - & - \\
\hline Dyella sp. & - & - & - & - & - & 1 & - & 1 & - & - & - & 1 \\
\hline Enterobacter sp. & 8 & 3 & - & 2 & 1 & - & 1 & - & 2 & 1 & 4 & 4 \\
\hline Hafnia sp. & - & - & - & - & 5 & - & - & - & - & - & - & - \\
\hline Erwinia sp. & - & - & 1 & - & - & - & - & - & - & - & - & - \\
\hline Herbaspirillum sp. & - & - & 4 & 1 & - & - & 1 & - & - & - & 4 & - \\
\hline Klebsiella sp. & - & - & - & - & - & - & - & - & 3 & 1 & - & - \\
\hline Kluyvera sp. & - & - & - & - & - & - & - & - & - & - & - & 1 \\
\hline Leclercia sp. & - & - & 1 & 5 & 2 & - & - & - & - & - & - & - \\
\hline Lysobacter sp. & - & - & - & - & - & 1 & - & - & - & - & - & - \\
\hline Luteibacter sp. & 1 & 1 & - & - & - & - & - & - & - & 2 & - & - \\
\hline Microbacterium sp. & - & - & - & - & 1 & - & - & 3 & - & - & - & - \\
\hline Novosphingobium sp. & - & - & - & - & 1 & - & - & - & - & - & - & - \\
\hline Ochrobactrum sp. & 1 & - & - & - & 1 & 1 & - & - & - & - & - & - \\
\hline Pandoraea sp. & - & 1 & - & - & - & - & - & - & - & - & - & - \\
\hline Pantoea sp. & - & - & - & - & - & 2 & - & - & - & 1 & 4 & 2 \\
\hline Pedobacter sp. & - & 1 & - & - & - & - & - & - & - & - & - & - \\
\hline Pseudomonas sp. & 3 & 5 & 9 & 6 & 3 & 2 & 18 & 4 & 8 & 14 & 5 & 1 \\
\hline Raoultella sp. & - & - & - & - & 1 & - & - & - & - & - & - & - \\
\hline Rhizobium sp. & 6 & 4 & 5 & 5 & - & 6 & - & 1 & 1 & 1 & - & - \\
\hline Salmonella sp. & - & - & - & - & - & - & - & - & - & - & 1 & 3 \\
\hline Serratia sp. & 4 & - & 5 & - & 1 & 3 & - & - & - & - & - & - \\
\hline Shigella sp. & - & - & - & - & - & - & - & - & - & - & 5 & - \\
\hline Sphingobium sp. & - & - & - & - & 1 & - & - & - & - & - & - & - \\
\hline Sphingomonas sp. & - & - & 1 & 1 & 1 & - & - & - & - & - & - & - \\
\hline Stenotrophomonas sp. & 1 & - & - & - & - & 1 & 3 & 1 & 5 & 1 & 3 & - \\
\hline Variovorax sp. & 1 & - & - & - & - & - & - & - & - & - & - & - \\
\hline Xanthomonas sp. & 1 & - & 1 & 1 & - & - & - & - & - & - & 3 & - \\
\hline Unidentified & - & 2 & 1 & 1 & 5 & 5 & - & 1 & 1 & 2 & - & - \\
\hline Total & 30 & 29 & 29 & 30 & 29 & 29 & 32 & 29 & 28 & 30 & 30 & 21 \\
\hline$H^{\text {a } \mathrm{a}}$ & \multicolumn{2}{|c|}{2.31} & \multicolumn{2}{|c|}{2.18} & \multicolumn{2}{|c|}{2.80} & \multicolumn{2}{|c|}{1.40} & \multicolumn{2}{|c|}{1.82} & \multicolumn{2}{|c|}{2.35} \\
\hline
\end{tabular}

${ }^{a}$ Shannon diversity index.

${ }^{\mathrm{b}}$ Soil $=$ Rhizospheric Soil 
Table 3 - Heatmap associations of bacterial isolates and PGP traits both from roots and rhizospheric soil from each sampling site. Different shades show whether a certain location had more or fewer bacteria than expected. or whether there was no association. Black cells $=$ number of isolates lower than expected in that condition, dark shaded cells = number of isolates higher than expected in that condition, light shaded cells $=$ no significant differences between observed and expected values according to adjusted residual analysis $(p<0.05)$.

\begin{tabular}{|c|c|c|c|c|c|c|c|c|c|c|}
\hline \multirow[t]{2}{*}{ Sampling site } & & \multicolumn{3}{|c|}{ Siderophores production $^{\mathrm{a}}$} & \multicolumn{3}{|c|}{ Phosphate solubilization $^{\mathrm{a}}$} & \multicolumn{3}{|c|}{ Indolic compound production } \\
\hline & & 1 & 2 & 3 & 1 & 2 & 3 & 1 & 2 & 3 \\
\hline \multirow[t]{3}{*}{ Júlio de Castilhos } & Roots $^{\mathrm{b}}$ & 8 & 21 & 1 & 30 & 0 & 0 & 9 & 9 & 12 \\
\hline & R. Soil ${ }^{\mathrm{c}}$ & 17 & 12 & 0 & 26 & 3 & 0 & 8 & 12 & 9 \\
\hline & JC Total & 25 & 33 & 1 & 56 & 3 & 0 & 17 & 21 & 21 \\
\hline \multirow[t]{3}{*}{ São Borja } & Roots & 10 & 19 & 0 & 28 & 0 & 1 & 11 & 14 & 4 \\
\hline & R. Soil & 14 & 16 & 0 & 30 & 0 & 0 & 10 & 6 & 14 \\
\hline & SB Total & 24 & 35 & 0 & 58 & 0 & 1 & 21 & 20 & 18 \\
\hline \multirow[t]{3}{*}{ Vacaria } & Roots & 7 & 22 & 0 & 18 & 9 & 2 & 18 & 10 & 1 \\
\hline & R. Soil & 4 & 25 & 0 & 21 & 5 & 3 & 14 & 13 & 2 \\
\hline & VA Total & 11 & 47 & 0 & 39 & 14 & 5 & 32 & 23 & 3 \\
\hline \multirow[t]{3}{*}{ Campina das Missões } & Roots & 5 & 11 & 16 & 25 & 7 & 0 & 2 & 27 & 3 \\
\hline & R. Soil & 19 & 2 & 8 & 21 & 8 & 0 & 7 & 18 & 4 \\
\hline & CM Total & 24 & 13 & 24 & 46 & 15 & 0 & 9 & 45 & 7 \\
\hline \multirow[t]{3}{*}{ Guarani das Missões } & Roots & 14 & 9 & 5 & 24 & 4 & 0 & 0 & 19 & 9 \\
\hline & R. Soil & 19 & 8 & 3 & 25 & 5 & 0 & 2 & 23 & 5 \\
\hline & GM Total & 33 & 17 & 8 & 49 & 9 & 0 & 2 & 42 & 14 \\
\hline \multirow[t]{3}{*}{ Boa Vista do Cadeado } & Roots & 14 & 10 & 6 & 28 & 0 & 2 & 9 & 14 & 7 \\
\hline & R. Soil & 6 & 5 & 10 & 15 & 0 & 6 & 3 & 11 & 7 \\
\hline & BV Total & 20 & 15 & 16 & 43 & 0 & 8 & 12 & 25 & 14 \\
\hline Total & & 137 & 160 & 49 & 291 & 41 & 14 & 93 & 176 & 77 \\
\hline
\end{tabular}

${ }^{\mathrm{a}}$ Categories scored for plant growth promotion traits: 1 = non-siderophores producers, non-phosphate solubilizers or level 1 IC producers; 2 = level 2 siderophore producers, phosphate solubilizers or IC producers; $3=$ level 3 siderophores producers, phosphate solubilizers or IC producers.

${ }^{\mathrm{b}}$ Bacterial isolates obtained from roots.

${ }^{\mathrm{c} B a c t e r i a l}$ isolates obtained from rhizospheric soil.

Evaluation of the relationship between genera and PGP traits allowed the observation of certain patterns of association. One finding was a division between positive and negative values of dimension 1 (associated to Sid and Phos) when analyzing genera related to PGP traits (Figure. 2). A large number of genera grouped together with the ability to produce ICs (left side of the plot); levels 2 and 3 of phosphate solubilization ability and level 3 of siderophores production ability formed a second group (right side of the plot) and were related to fewer bacterial genera than for ICs production. The sampling site and niches (roots and rhizospheric soil) did not contribute significantly to the differences, so these data were not represented in the plot.

By focusing the analysis on the most abundant genera, it was observed that, regardless of the sampling site or niche, strains belonging to the genus Burkholderia were strongly related to nutrient uptake (either phosphate solubilization or siderophores production). This genus is associated with siderophores production at level 3 , both in the roots and in rhizospheric soil, and also associated with phosphate solubilization at level 2 in the roots and at levels 2 and 3 in rhizospheric soil. Interestingly, this genus was associated with poor ICs production in the rhizospheric soil (more level 1 producers and less level 3 producers than expected, according to chi-square analysis), and average production in root isolates (more level 2 producers and less level 1 producers than expected). Isolates belonging to Enterobacter genus were found related to phosphate solubilization (level 3 in roots) and level 3 ICs production both in roots and in rhizospheric soil. These and other significant associations are shown on Table 3 and Figure 2.

Differences in the community structure associated to the sampling site and niche can be observed in Figure 3. Bacterial samples isolated from the JC and SB localities shared similar composition, possessing most of the strains belonging to the genera Rhizobium and Azospirillum; bacterial samples isolated from the CM and GM localities were also associated, mainly composed of strains belonging to the genera Burkholderia, Pseudomonas, and Stenotrophomonas. The bacterial sample isolated from the BV locality was distinct from all other regions and was mainly composed of strains belonging to the genera Enterobacter and Herbaspirillum. Similar behavior was observed for the bacterial sample isolated from the VA lo- 
cality, although this sample did not have a strong relationship with any particular bacterial genus. Association of the most representative genera, according to locality and whether in the roots or in rhizospheric soil, are demonstrated in Table 2.

PGP traits were also associated with locality and niche. Association between PGP traits and locality, as well as the effect of niche in each locality are shown in Table 3.

\section{Discussion}

Despite the fact that all sampling sites analyzed were traditionally used to crop wheat and that all sampled plants were at the same stage of maturity, Principal Coordinate Analysis (PCA) was able to separate the regions into distinct groups according to their soil characteristics and diversity indices. Clay, $\mathrm{pH}$, and organic matter contents may exert influence on bacterial diversity and survival (Palmer and Young, 2000). Lower levels of bacterial diversity and richness might be observed in acidic soils; in a way that $\mathrm{pH}$ could be one of the best predictor of soil bacterial diversity and richness (Fierer and Jackson, 2006). As observed in the PCA analysis, $\mathrm{pH}$ is strongly associated to diversity index ( $H^{\prime}$ value). However, the bacterial sample communities from Júlio de Castilhos (JC) and São Borja (SB) localities that presented very similar $\mathrm{pH}$ values and also clustered together with those from GM and CM localities in the PCA analysis, presented much higher diversity indices ( 2.31 and 2.18 , respectively). This result suggested that $\mathrm{pH}$ should not be the only factor considered for microbiological diversity estimates. Although little information is available about the specific effects of parameters such as organic carbon and total nitrogen content of the soil on microbial diversity, information such as organic carbon and total nitrogen content could also affect the diversity of soil bacteria, including nitrogen-fixing bacteria (Ramette and Tiedje, 2007). The Vacaria locality was the most distinctive geographical area and it also presented the lowest $\mathrm{P}$ content, the highest organic matter content, and the highest $H^{*}$ value (2.8). Together, these features could justify its position in the PCA analysis, which was separate from all samples. Similar behavior was observed for the Boa Vista do Cadeado (BV) locality, which also appeared isolated from the other sites in the PCA analysis, likely due to its most distinctive parameter, reduced organic matter content.

Various studies concerning plant-associated bacterial communities are able to shed light on factors driving microbial composition, especially regarding taxonomical distribution linked to function. 16S rRNA profiling and advanced metagenomics are powerful tools for the characterization of such populations (e.g. Bulgarelli et al., 2012; Lundberg et al., 2013). For example, Bulgarelli et al. (2012) conclude that $40 \%$ of the colonizing bacteria of Arabidopsis thaliana roots were due to the presence of plant cell wall residues instead of soil or plant specificity.
The isolates identified here were assigned to 36 genera belonging to 17 families. The most abundant family was Pseudomonadaceae, which comprised strains belonging to the most abundant genus identified, Pseudomonas. Species from this genus are known as nitrogen-fixing bacteria in various ecosystems and are commonly isolated from the rhizosphere of gramineae plants (Mirza et al., 2006; Ambrosini et al., 2012). Germida and Siciliano (2001) studied microbial communities from old, recent and modern wheat cv. and observed that modern cv., (such as Guamirim), are more aggressively colonized by Pseudomonas strains. Enterobacteriaceae was the second most abundant family identified in this study. Members of this family are related to phosphorus solubilization (Chen et al., 2006) and are known to improve plant growth (MoralesGarcía et al., 2011). In fact, almost half of the strains identified in this study as phosphate solubilizers belonged to the Enterobacteriaceae family. In addition, strains belonging to the genus Enterobacter were found to produce higher amounts of indolic compounds (ICs) and to be widely associated both with roots and rhizospheric soils. The improved production of ICs by the Enterobactereacea group is supported in Costa et al. (2014), in which a wider range of isolates related to various crops than wheat were evaluated.

The second most abundant genus identified in this study (Burkholderia) has become a controversial genus given the duality of two major groups. Through molecular analysis, Perin et al. (2006) observed a distinct separation between the Burkholderia species that are plant-associated and generally beneficial to those plants and those that are either plant or opportunistic mammalian pathogens. Burkholderia species were found nodulating leguminous plants a few years ago (Chen et al., 2005). Thus, it is being suggested that the nitrogen-fixing species of the Burkholderia group should be placed in a new genus (Gyaneshwar et al., 2011). It is not surprising that the Burkholderia species were found to be associated with the ability of nutrient uptake regardless of the collection site or the type of association with the plant. Many authors have reported the role of strains belonging to this genus in increasing plant phosphorus uptake (e.g., Unno et al., 2005; Compant et al., 2008). Indeed, 27 out of the 55 isolates able to solubilize phosphate belonged to the genus Burkholderia, whereas the remaining isolates were mostly represented by strains belonging to the Enterobacteriaceae family. Many of the studies cited in this work have been conducted aiming the prospection of PGPBs and their application for wheat culture and, not infrequently, the objects of these studies are bacteria belonging to the genera Rhizobium and Azospirillum. However, Burkholderia isolates may represent a new field for inoculation purposes due to its exceptional metabolic versatility, functional diversity and dominant presence in many soil ecosystems (Coenye and Vandamme, 2003). 
As compared to the high number of isolates able to produce ICs and siderophores, a low number of strains was observed as able to solubilize phosphate. As the soils collected for this study were under regular regime of phosphate fertilization, the present result is in accordance with $\mathrm{Hu}$ et al. (2009), who found that P-solubilizing bacteria are more metabolically active in P-deficient fertilized soils after long-term fertilizer management. Although the tricalcium phosphate solubilization assay has been used for several years, it does not recreate the complexity of phosphorus in soil environments, that include common forms of phosphate that are more difficult to solubilize, such as Fe-P and Al-P (Bashan et al., 2013). Thus we must be aware that the isolates that were considered as phosphate solubilizers might be unable to solubilize all $\mathrm{P}$ sources in natural soils.

The ability to produce siderophores, however, was frequently demonstrated by more than $60 \%$ of the bacterial isolates. On the other hand, without exception, all isolates were able to produce ICs; the majority of which did so in high amounts. The occurrence of these PGP traits is in accordance with the literature (Guerinot, 1994; Spaepen et al., 2007; Hayat et al., 2010). Costa et al. (2013) found that the number of good IC producers increased when plants were subjected to light fertilization conditions as compared to zero and high fertilizer inputs. Considering this, although it was not evaluated in this study, the high number of IC producers was in agreement with the suitable nutrient condition ( $\mathrm{P}, \mathrm{K}$, and organic matter content) of the soils regarding to the harboring crop (wheat). Indeed, phosphate solubilizer strains were identified more frequently in the rhizospheric soil samples; while siderophores producers were identified in larger number and more often closely related to the roots, whereas IC producers were equally distributed in roots and soil. These different occurrences of PGP traits between rhizospheric soil and root related to bacterial samples suggests that, in the case of IC producers, the bacterial samples present in these two niches are similarly influenced by the plant exudates. Such observations provide an idea of the plant's needs. The vegetal system tends to apply selective pressure over the microbial community, in order to enrich the vicinity of plant roots with beneficial bacteria, through the modulation of root exudates (Dennis et al., 2010). Even though siderophores might be able to migrate, the present results enable us to infer that there is a preference on siderophores production, which comes along with ICs production, rather than phosphate solubilizers in the agricultural wheat crops in this study.

Although the analyzed plants were under the same fertilization regime, it was possible to visualize differences in the distribution and structure of PGPB communities associated with wheat. MCA and CatPCA were useful to establish visual relationships for a large set of data; most of them confirmed through chi-square and adjusted residual analysis. Most of the relationships between the sampling sites in the results of PCA were supported by the results of MCA (Figure 3). Distribution of genera according to their frequency and homogeneity strongly link the JC and SB localities, in other words, these sampling sites might share similar communities. CM and GM localities, despite their geographical proximity, presented some differences in their bacterial communities; whereas the VA and BV localities remained separate from the other localities and from each other, possibly due to the same distinctive parameters inferred by PCA analysis: altitude (not evaluated) and organic matter content. Thus, the shifts in diazotrophic communities could not be linked to the direct geographic distance between sites, such as reported by Wakelin et al. (2010).

PGP traits were also associated to locality; however, the analysis of these associations was non-conclusive. For example, the bacterial community from the VA locality lacks phosphate solubilization activity although this site also lacks phosphorus content in soil. As a low number of phosphate solubilizers were found, it is correct to infer that organisms other than the cultivable diazotrophic community, such as mycorrhizal fungi, could supply this particular nutrient. The bacterial samples from BV and CM localities contain the best siderophores producers (strongly associated with the production of level 3); that from GM locality is associated with non-siderophores production. The bacterial samples from JC, SB and VA localities did not present a high number of siderophores producers, and in those from SB and VA localities we found a moderate number of siderophores producers, clearly expressing diversity among localities.

MCA and CatPCA became a useful tool to identify the relationships between bacterial diversity, functional traits of plant growth promotion and sampling sites, and became a starting point to pursue the objectives of the study. In particular, they showed a clear separation of bacterial strains belonging to certain genera that were able to solubilize nutrients from those able to produce ICs in this system. This information combined to what can be inferred about the plant's needs (i.e. siderophores production preferentially expressed close to the roots, phosphate solubilization in the rhizosphere, and indolic compound production in both) in the present conditions, may help further studies to drive the prospection of PGPB regarding the desired organism and PGP trait.

\section{Acknowledgments}

This work was financed by a grant and fellowships from the Conselho Nacional de Desenvolvimento Científico e Tecnológico (CNPq/Brazil) and the Instituto Nacional de Ciência e Tecnologia (INCT) da Fixação Biológica do Nitrogênio (Brazil). 


\section{References}

Ambrosini A, Beneduzi A, Stefanski T, Pinheiro FG, Vargas LK and Passaglia LMP (2012) Screening of plant growth promoting rhizobacteria isolated from sunflower (Helianthus annuus L.). Plant Soil 356:245-264.

Baldani V, Baldani JI and Döbereiner J (1983) Effects of Azospirillum inoculation on root infection and nitrogen incorporation in wheat. Can J Microbiol 29:924-929.

Bashan Y, Kamnev AA and de-Bashan LE (2013) Tricalcium phosphate is inappropriate as a universal selection factor for isolating and testing phosphate-solubilizing bacteria that enhance plant growth: a proposal for an alternative procedure. Biol Fertil Soils 49:465-479.

Bulgarelli D, Rott M, Schlaeppi K, van Themaat EVL, Ahmadinejad N, Assenza F, Rauf P, Huettel B, Reinhardt R, Schmelzer E, et al. (2012) Revealing structure and assembly cues for Arabidopsis root-inhabiting bacterial microbiota. Nature 488:91-95.

Chen W-M, de Faria SM, Straliotto R, Pitard RM, Simões-Araújo JL, Chou Y-J, Chou J-H, Barrios E, Prescott AR, Elliott GN, et al. (2005) Proof that Burkholderia forms effective symbioses with legumes: a study of novel Mimosa-nodulating strains from South America. Appl Environ Microbiol 71:7461-7471.

Chen YP, Rekha PD, Arun AB, Shen FT, Lai W-A and Young CC (2006) Phosphate solubilizing bacteria from subtropical soil and their tricalcium phosphate solubilizing abilities. Appl Soil Ecol 34:33-41.

Coenye T and Vandamme P (2003) Diversity and significance of Burkholderia species occupying diverse ecological niches. Environ Microbiol 5:719-729.

Compant S, Nowak J, Coenye T, Clément C and Barka EA (2008) Diversity and occurrence of Burkholderia spp. in the natural environment. FEMS Microbiol Rev 32:607-626.

Costa PB, Beneduzi A, Souza R, Schoenfeld R, Vargas LK and Passaglia LMP (2013) The effects of different fertilization conditions on bacterial plant growth promoting traits: guidelines for directed bacterial prospection and testing. Plant Soil 368:267-280.

Costa PB, Granada CE, Ambrosini A, Moreira F, de Souza R, Passos JFM, Arruda L and Passaglia LMP (2014) A Model to explain plant growth promotion traits: a multivariate analysis of 2,211 bacterial isolates. PLoS ONE 9:e116020.

Dennis PG, Miller AJ and Hirsch PR (2010) Are root exudates more important than other sources of rhizodeposits in structuring rhizosphere bacterial communities? FEMS Microbiol Ecol 72:313-327.

Döbereiner J (1988) Isolation and identification of root associated diazotrophs. Plant Soil 110:207-212.

Felske A, Rheims H, Wokerink A, Stackebrandt E and Akkermans DL (1997) Ribosome analysis reveals prominent activity of an uncultured member of the class Actinobacteria in grasslands soils. Microbiology 143:2983-2989.

Fierer N and Jackson RB (2006) The diversity and biogeography of soil bacterial communities. Proc Natl Acad Sci U S A 103:626-631.

Germida JJ and Siciliano SD (2001) Taxonomic diversity of bacteria associated with the roots of modern, recent and ancient wheat cultivars. Biol Fertil Soils 33:410-415.

Glickmann E and Dessaux Y (1995) A critical examination of the specificity of the Salkowskir eagent for indolic compounds produced by phytopathogenic bacteria. Appl Environ Microbiol 61:793-796.

Guerinot ML (1994) Microbial iron transport. Annu Rev Microbiol 48:743-772.

Gyaneshwar P, Hirsch AM, Moulin L, Chen WM, Elliott GN, Bontemps C, Estrada-de Los Santos P, Gross E, dos Reis FB, Sprent JI, et al. (2011) Legume-nodulating betaproteobacteria: diversity, host range, and future prospects. Mol Plant Microbe Interact 24:1276-1288.

Hartmann A, Schmid M, van Tuinen D and Berg G (2009) Plantdriven selection of microbes. Plant Soil 321:235-257.

Hayat R, Ali S, Amara U, Khalid R and Ahmed I (2010) Soil beneficial bacteria and their role in plant growth promotion: a review. Ann Microbiol 60:579-598.

Helmke PA and Sparks DL (1996) Lithium, sodium, potassium, rubidium, and cesium. In: Sparks DL (ed) Methods of soil analysis. Part 3. Chemical methods. SSSA Book Series No. 5. SSSA and ASA, Madison, WI. pp 551-574.

Hoffman DL (1992) Interpreting Multiple Correspondence Analysis as a multidimensional scaling method. Market Lett $3: 259-272$.

Hu J, Lin X, Wang J, Chu H, Yin R and Zhang J (2009) Population size and specific potential of P-mineralizing and -solubilizing bacteria under long-term P-deficiency fertilization in a sandy loam soil. Pedobiologia 53:49-58.

James EK, Gyaneshwar P, Mathan N, Barraquio QL, Reddy PM, Iannetta PPM, Olivares FL and Ladha JK (2002) Infection and colonization of rice seedlings by the plant growthpromoting bacterium Herbaspirillum seropedicae Z67. Mol Plant Microbe Interact 15:894-906.

Kennedy IR, Choudhury ATMA and Kecske's ML (2004) Nonsymbiotic bacterial diazotrophs in crop-farming systems: can their potential for plant growth promotion be better exploited? Soil Biol Biochem 36:1229-1244.

Kuo S (1996) Phosphorus. In: Sparks DL (ed) Methods of soil analysis. Part 3. Chemical methods. Soil Sci. Soc. Am. Book Series: 5. Soil Sci. Soc. Am. Madison, WI, pp 8669-920.

Lugtenberg B and Kamilova F (2009) Plant-Growth-Promoting Rhizobacteria. Annu. Rev Microbiol 63:541-556.

Lundberg DS, Yourstone S, Mieczkowski P, Jones CD and Dangl JL (2013) Practical innovations for high-throughput amplicon sequencing. Nat Methods 10:999-1002.

Mirza MS, Mehnaz S, Normand PM, Prigent-Combaret C, Moënne-Loccoz Y, Bally R and Malik KA (2006) Molecular characterization and PCR detection of a nitrogen fixing Pseudomonas strain promoting rice growth. Biol Fertil Soils 43:163-170.

Morales-García YE, Juárez-Hernández D, Aragón-Hernández C, Mascarua-Esparza MA, Bustillos-Cristales MR, FuentesRamírez LE, Martínez-Contreras RD and Muñoz-Rojas J (2011) Growth response of maize plantlets inoculated with Enterobacter spp., as a model for alternative agriculture. Rev Argent Microbiol 43:287-293.

Mulvaney RL (1996) Nitrogen - inorganic forms. In: Sparks DL (ed.) Methods of soil analysis. Part 3. Chemical methods. SSSA Book Series No. 5. SSSA and ASA, Madison, WI, pp 1123-1184.

Nelson DW and Sommers LE (1996) Total carbon, organic carbon, and oganic matter. In: Sparks DL (ed.) Methods of soil analysis. Part 3. Chemical methods. SSSA Book Series No. 5. SSSA and ASA, Madison, WI, pp 961-1010. 
Palmer KM and Young JPW (2000) Higher diversity of Rhizobium leguminosarum biovar viciae populations in arable soils than in grass soils. Appl Environ Microbiol $66: 2445-2450$

Perin L, Martínez-Aquilar L, Castro-González R, Estrada-delos Santos P, Cabbellos-Avelar T, Guedes HV, Reis VM and Caballero-Mellado J (2006) Diazotrophic Burkholderia species associated with field-grown maize and sugarcane. Appl Environ Microbiol 72:3103-3110.

Ramette A and Tiedje JM (2007) Multiscale responses of microbial life to spatial distance and environmental heterogeneity in a patchy ecosystem. Proc Natl Acad Sci U S A 104:27612766.

Sambrook J and Russel DW (2001) Molecular cloning: a laboratory manual. Cold Spring Harbor Laboratory Press, NewYork.

Schwyn B and Neilands JB (1987) Universal chemical assay for the detection and determination of siderophores. Anal Biochem 160:47-56.

Shannon CE and Weaver W (1949) The mathematical theory of communication. University of Illinois Press, Urbana,19 p.

Spaepen S, Vanderleyden J and Remans R (2007) Indole-3-acetic acid in microbial and microorganism-plant signaling. FEMS Microbiol Rev 31:425-448.

Tilman D (2001) Functional diversity. In: Levin SA (ed) Encyclopedia of Biodiversity. Elsevier, Oxford, pp 109-120.

Unno Y, Okubo K, Wasaki TS and Osaki M (2005) Plant growth promotion abilities and microscale bacterial dynamics in the rhizosphere of lipin analyzed by phytate utilization ability. Environ Microbiol 7:396-404.

Wakelin SA, Gupta VVSR and Forrester ST (2010) Regional and local factors affecting diversity, abundance, and activity of free-living, N2-fixing bacteria in Australian agricultural soils. Pedobiology 53:391-399.

Wartiainen I, Eriksson T, Zheng W and Rasmussen U (2008) Variation in the active diazotrophic community in rice paddy: nifH PCR-DGGE analysis of rhizosphere and bulk soil. Appl Soil Ecol 39:65-75.

\section{Internet Resources}

EzTaxon database, http://eztaxon-e.ezbiocloud.net/ (accessed on October, 10 ${ }^{\text {th }}, 2015$ )

\section{Supplementary Material}

The following online material is available for this article:

Table S1 - Input dataset for MCA analysis.

Table S2 - Input dataset for CatPCA analysis.

This material is available as part of the online article from http:/www.scielo.br/gmb.

Associate Editor: Célia Maria de Almeida Soares

License information: This is an open-access article distributed under the terms of the Creative Commons Attribution License (type CC-BY), which permits unrestricted use, distribution and reproduction in any medium, provided the original article is properly cited. 